Risk of prostate cancer in relation to farming exposure in different races

\section{Farming and prostate cancer}

\section{Vilhjalmur Rafnsson}

\section{Commentary on paper by Meyer et al (see page 155)}

$\mathrm{T}$ here is ample published literature already available on prostate cancer in farmers, but Meyer et al contribute additional insights on risk factors related to farming in a population-based casecontrol study presented in this issue. Farmers are generally thought to enjoy a healthy lifestyle; they tend to smoke less and consume less alcohol, and to obtain more physical exercise than other groups. ${ }^{2}$ However, they have occupational exposure of interest, including exposures to a variety of chemicals, such as pesticides, herbicides, fertilisers, solvents, engine exhaust gases and organic dust, and biological agents such as zoonotic viruses, bacteria and fungi. ${ }^{2}{ }^{3}$ Although these exposures are varied, a discussion of risk factors related to contracting certain types of cancer, in particular prostate cancer, often tends to be focused only on pesticides. Some of the reviews on prostate cancer and farmers indicate an association with pesticides, ${ }^{4}$ whereas others are not conclusive with regard to the actual risk factors for what seems to be a slightly higher risk of prostate cancer among farmers. ${ }^{3}$

In previous studies on farmers, it has been pointed out that it would be wise to subcategorise farmers into farm owners, foremen and farm hands, ${ }^{3}$ an issue that Meyer et al regretted not having taken into consideration in designing their study. ${ }^{1}$ Others have emphasised that an attempt should be made to evaluate the role of specific agricultural chemicals in relation to the prostate cancer risk among farmers and pesticide applicators. ${ }^{.}$The association between pesticide and prostate cancer risk has also been investigated among pesticide applicators and pesticide manufacturing workers in two recent meta-analyses, ${ }^{67}$ but the authors were not able to draw firm conclusions on the role of specific pesticides or other chemicals in the increased risk of prostate cancer.

What is novel in the study by Meyer et al is its results on prostate cancer and farming activities of African-Americans, a population with a high incidence of prostate cancer. ${ }^{8} \mathrm{~A}$ recent study found an African cohort with a high rate of this cancer. ${ }^{9}$ The importance of this is clear, as there was only one previous study on incidence cases of prostate cancer, ${ }^{10}$ and another proportional mortality study $y^{11}$ of farming among African-Americans. Both the proportional mortality study $y^{11}$ and a case-control study ${ }^{10}$ provide some support for an association between prostate cancer risk and farming. It has been pointed out previously in a meta-analysis of white male farmers that proportional mortality studies and case-control studies find an elevated risk for prostate cancer, whereas follow-up studies do not. ${ }^{12}$ The metaanalysis also shows that the increased risk for prostate cancer among farmers was confined to studies from North America, and not found in European studies. ${ }^{12}$

Meyer $e t a^{1}$ discuss their finding that farming was associated with an increased risk of prostate cancer in Caucasians but not in African-Americans. They conclude that the increased risk of prostate cancer among white farmers may be attributable to pesticide exposure, whereas the lack of similar findings among African-American may be explained by a difference in farming activities and genetic or environmental factors. Their study seems to have a minimal risk of misclassification of cases and controls owing to its use of the South Carolina cancer registry. On the other hand, the information on exposure (years of farming, recent farming experience, and specific farming activities) was collected by interviews after the cases occurred, with the inherent weakness of retrospective studies. ${ }^{1}$ Before the advent of cancer registries, information on cancer cases obtained in interviews had to be verified by scrutinising individual medical records. Experience and custom should perhaps be adopted to confirm employment history through payroll and employment records in future retrospective occupational studies.

In their study, Meyer et al were able to locate proportionally more cases than controls, thus raising the question of whether access to information on exposure was influenced by the outcome. Is it easier to locate an individual with a serious disease, who has recently had contact with healthcare services, than a person without the serious disease? The disproportion between located African-Americans compared with Caucasians was even larger, which could perhaps partly explain the different risk of prostate cancer in relation to farming exposure in different races. It is also noteworthy that the number of digital rectal examinations and tests for prostatespecific antigens in the past 5 years differed substantially between cases and controls, raising thoughts as to whether there may be an overdetection of prostate cancer among cases and underdetection of prostate cancer among controls. These variables are connected to individual behaviour; however, they are also related to other factors that can influence selection into the study such as family history of prostate cancer and benign prostatic hyperplasia. The fact that many doctors, but not all, currently look for prostate cancer in their patients (only in a few areas is this an organised, systematic screening activity directed to the general population), possibly to a varying extent in different racial groups, may result in misclassification of cases and controls, something that should be taken into consideration in future analytical studies on prostate cancer.

Occup Environ Med 2007;64:143.

doi: 10.1136/oem.2006.030932

Correspondence to: Professor V Rafnsson, Department of Preventive Medicine, University of Iceland, Neshaga 16, 107 Reykjavík, Iceland; vilraf@hi.is

Competing interests: None declared.

\section{REFERENCES}

1 Meyer TE, Coker AL, Sanderson M, et al. A casecontrol study of farming and prostate cancer in African-American and Caucasian men. Occup Environ Med 2007;64:155-60.

2 Blair A, Hoar Zahm SH, Pearch NE, et al. Clues to cancer etiology from studies of farmers. Scand J Work Environ Health 1992;18:209-15.

3 Van Der Dulden JWJ, Vogelzang PFJ. Framers at risk for prostate cancer. Br J Urol 1996;77:6-14.

4 Keller-Byrne JE, Khuder SA, Schuab EA. Meta analyses of prostate cancer and farming. Am J Ind Med 1997;31:580-6.

5 Alavanja MCR, Samanic C, Dosemeci M, et al. Use of agricultural pesticide and prostate cancer risk in agricultural health study cohort. Am J Epidemiol 2003;157:800-14.

6 Van Maele-Fabry G, Willems JL. Prostate cancer among pesticide applicators: a meta-analysis. Int Arch Occup Environ Health 2004;77:559-70.

7 Van Maele-Fabry G, Libotte V, Willems JL, et al. Review and meta-analysis of risk estimates for prostate cancer in pesticide manufacturing workers. prostate cancer in pesticide manufacturing

8 Parkin DM, Whelan SL, Ferlay J, et al. Cancer incidence in five continents, IARC Scientific Publication Number 155. Lyon: IARC, 2003.

9 Angwafo FF, Zaher A, Befidi-Mengue R, and the National Health Survey Team of the National Epidemiology Board of Cameroon, et al. Highgrade intra-epithelial neoplasia and prostate cancer in Dibombari, Cameroon. Prostate Cancer Prostatic Dis 2003;6:334-8.

10 Krstev S, Baris D, Stewart P, et al. Occupational risk factors and prostate cancer in U.S. blacks and whites. Am J Ind Med 1998;34:421-30.

11 Dosemeci M, Hoover RN, Blair A, et al. Farming and prostate cancer among African-Americans in the southeastern United States. J Natl Cancer Inst 1994;86:1718-19.

12 Acqavella J, Olsen G, Cole P, et al. Cancer among farmers: a meta-analysis. Ann Epidemiol 1998;8:64-74. 